\title{
The effect of glycerol on nutrient digestibility in finishing pigs
}

M E E McCann ${ }^{1,2}$, E Magowan ${ }^{1}, \mathrm{~K}$ J McCracken ${ }^{2}$, V E Beattie ${ }^{3}$, F J Gordon ${ }^{4}, \mathrm{M}$ D Scott ${ }^{3}$, A Thompson ${ }^{4}$, R Bradford ${ }^{5}$

${ }^{1}$ Agri-Food and Biosciences Institute, Hillsborough, United Kingdom, ${ }^{2}$ Queen's University of Belfast, Belfast, United Kingdom, ${ }^{3}$ Devenish Nutrition Ltd, Belfast, United Kingdom, ${ }^{4}$ John Thompson and Son Ltd, Belfast, United Kingdom, ${ }^{5}$ Perferred Capital Management, Belfast, United Kingdom

Email:Elizabeth.McCann@afbini.gov.uk

Introduction McCann et al (2009) reported that glycerol inclusion lowered the growth rate of pigs and that there was a tendency for feed conversion to become less efficient as glycerol inclusion increased. These findings suggested that the digestible energy (DE) content of glycerol is lower than that from a starch source such as wheat. There has been very little work conducted on the nutritive value of glycerol for pigs and the aim of this trial was therefore to investigate the effect of increasing glycerol inclusion on nutrient utilisation in finishing pigs.

Materials and methods Four experimental diets were offered to 24 Landrace x Large White boars (45kg) housed in individual metabolism crates for 14 days ( 7 days pre-feed and 7 days total collection of urine and faeces). The experimental diets contained $0,40,80$ and $120 \mathrm{~g} / \mathrm{kg}$ crude glycerol and were formulated to be isoenergetic and isonitrogenous $(15.8 \mathrm{MJ} / \mathrm{kg}$ dry matter (DM) DE and $10.8 \mathrm{~g} / \mathrm{kg}$ DM lysine). The crude glycerol contained $850 \mathrm{~g} / \mathrm{kg}$ glycerol and DE content was assumed to be $15.8 \mathrm{MJ} / \mathrm{kg}$ (fresh basis). The basal diet contained (g/kg) wheat 437, barley 300, soyabean meal 227 , vegetable oil 13.6, limestone 9, dicalcium phosphate 3, salt 4.1, lysine 0.8 and minerals and vitamins 5. Glycerol replaced wheat in the diet formulation. Diets and faeces were analysed for DM, crude protein (CP), lipid (oil procedure B) energy and neutral detergent fibre (NDF) to determine nutrient digestibility and dietary DE content.

Results There was a significant quadratic effect of glycerol inclusion on DM, CP and energy digestibility and on dietary DE content (Table 1). Glycerol inclusion at 40 and $80 \mathrm{~g} / \mathrm{kg}$ improved DM, CP and energy digestibility and DE content relative to the control diet but there was no difference in nutrient utilisation of the diets containing 0 and $120 \mathrm{~g} / \mathrm{kg}$ glycerol. According to quadratic regression statistics for DE content, the optimum inclusion rate of glycerol was $74 \mathrm{~g} / / \mathrm{kg}$. Actual dietary DE content of the control diet was lower than the formulated DE content (15.4 vs. $15.8 \mathrm{MJ} / \mathrm{kg} \mathrm{DM})$ and DE contents of the diets containing 40 and $80 \mathrm{~g} / \mathrm{kg}$ glycerol were higher than the control diet.

Table 1 The effect of glycerol on nutrient utilisation

\begin{tabular}{lcccccccc}
\hline \hline & $0 \mathrm{~g} / \mathrm{kg}$ & \multicolumn{1}{c}{$40 \mathrm{~g} / \mathrm{kg}$} & \multicolumn{1}{c}{$80 \mathrm{~g} / \mathrm{kg}$} & $120 \mathrm{~g} / \mathrm{kg}$ & $\mathrm{SEM}$ & $\mathrm{P}$ & $\mathrm{P}=\mathrm{LIN}$ & $\mathrm{P}=\mathrm{QU} \mathrm{AD}$ \\
\hline DM digestibility & $0.852^{\mathrm{a}}$ & $0.871^{\mathrm{b}}$ & $0.868^{\mathrm{b}}$ & $0.855^{\mathrm{a}}$ & 0.0038 & $<0.01$ & $\mathrm{NS}$ & $<0.001$ \\
CP digestibility & $0.839^{\mathrm{ab}}$ & $0.859^{\mathrm{b}}$ & $0.861^{\mathrm{b}}$ & $0.826^{\mathrm{a}}$ & 0.0077 & $<0.05$ & $\mathrm{NS}$ & $<0.01$ \\
Energy digestibility & $0.850^{\mathrm{a}}$ & $0.868^{\mathrm{b}}$ & $0.867^{\mathrm{b}}$ & $0.855^{\mathrm{ab}}$ & 0.0042 & $<0.05$ & $\mathrm{NS}$ & $<0.01$ \\
Lipid digestibility & 0.719 & 0.725 & 0.724 & 0.713 & 0.0093 & $\mathrm{NS}$ & $\mathrm{NS}$ & $\mathrm{NS}$ \\
DE (MJ/kg DM) & $15.44^{\mathrm{a}}$ & $15.83^{\mathrm{b}}$ & $15.85^{\mathrm{b}}$ & $15.73^{\mathrm{ab}}$ & 0.076 & $<0.01$ & $\mathrm{NS}$ & $<0.01$ \\
\hline \hline
\end{tabular}

Conclusions The results indicate that glycerol inclusion at 40 or $80 \mathrm{~g} / \mathrm{kg}$ improves nutrient utilisation but inclusion at $120 \mathrm{~g} / \mathrm{kg}$ does not. This quadratic effect may be because of saturation of glycerol kinase by glycerol at the higher inclusion level, thus preventing glycerol being metabolised and representing an energy cost to excrete the excess glycerol (Doppenberg and van der Aar 2007). This theory is supported by the findings on pig growth reported by McCann et al (2009) who found that glycerol inclusion at $120 \mathrm{~g} / \mathrm{kg}$ had a negative effect on liveweight gain. The lower than expected DE content for the control diet indicates that the DE content for the basal ingredients were overestimated in the formulation matrix and the higher than expected DE content for the diets containing glycerol suggests that the assumed value for glycerol DE content was underestimated. The improvement in DE content over the control diet, at lower levels of glycerol inclusion, is in line with effects observed in broiler studies (Griffiths and McCann 2009) and it can be concluded that glycerol may be a useful source of energy for finishing pigs. The maximum inclusion rate of glycerol to optimise dietary $\mathrm{DE}$ content was found to be $74 \mathrm{~g} / \mathrm{kg}$.

Acknowledgments This work was supported by the Department of Agriculture and Rural Development for Northern Ireland, John Thompson and Son Ltd. and Devenish Nutrition Ltd.

\section{References}

Doppenberg, J. \& van der Aar, P. 2007. Biofuels : Implications for the feed industry. Wageningen Academic Publishers. McCann, M.E.E., Magowan, E., Beattie, V.E., McCracken, K.J., Gordon, F.J., Scott, M.D., Robinson, M-J. and Bradford, R. 2009. The use of glycerol in diets for finishing pigs. Proceedings of the British Society of Animal Science, 104.

Griffiths, L. and McCann, M.E.E. 2009. The effect of glycerol inclusion on broiler performance and nutrient digestibility. British Poultry Science Abstracts 5 (1), 10-11. 